\title{
Kinerja Dinas Perdagangan Kota Padang dalam Melakukan Pengawasan Terhadap Penggunaan Bejana SPBU di Kota Padang
}

\author{
Nanda Dila Sarevi' ${ }^{1}$, Adil Mubarak ${ }^{2}$
}

\section{Universitas Negeri Padang}

Email: nandadila96@gmail.com, adilmubarak08@yahoo.co.id

\begin{abstract}
Abstrak
Pelaksanaan Keputusan Direktur Jendral Perdagangan Dalam Negeri Nomor 23/PDN/KEP/3/2010 belum di implementasikan dengan baik oleh pemilik alat-alat UTTP salah satu diantaranya adalah kepemilikan Bejana. Seabanyak 11 SPBU di Kota Padang yang menggunakan Bejana tidak mengikuti peraturan yang telah ditetapkan oleh Pemerintah. Akibatnya bejana tersebut tidak bisa dilakukan kalibrasi oleh Balai Metrologi dan menyebabkan status bejana tersebut menjadi ilegal. Pengawas kemetrologian Dinas Perdagangan KotaPadang terus melakukan pengawasan, pemeriksaan, serta memberikan himbauan kepada seluruh pemilik alat UTTP untuk mengimplementasikan hukum dengan baik. Penelitian ini bertujuan untuk mengetahui kinerja Dinas Perdagangan Kota Padang dalam melakukan pengawasan terhadap penggunaan Bejana SPBU di Kota Padang. Penelitian ini merupakan penelitian kualitatif dengan metode deskriptif. Informan penelitian ditentukan dengan teknik purposive sampling dan random sampling yaitu Dinas Perdagangan Kota Padang, UTTP Balai Metrologi, SPBU, dan masyarakat. Hasil penelitian menunjukkan bahwa Kinerja Pengawasan Kemetrologian belum optimal. Hal ini disebabkan oleh beberapa kendala yang ditemui dilapangan seperti kurangnya jumlah tenaga ahli, sarana dna prasarana, anggaran. Upaya yang dilakukan adalah pengajuan untuk menambah jumlah persoil tenaga ahli, menggunakan sarana dan prasarana dengan baik, pengajuan tambahan anggaran kepada pemerintah dan melakukan sosialisasi serta himbauan kepada pemilik UTTP.
\end{abstract}

Kata kunci: Kinerja, Dinas Perdagangan, Pengawasan.

The implementation of decision of the Director General of Domestic Trade No. 23/PDN/KEP/3/2010 has not been properly implemented by the owner of the measuring instruments, weighing instruments and the equipment, one of which is a vessel. As many as 11 gas stations in Padang City using vessels disregards the regulation that has been rule by the government. As an impact, the vessel can not be calibrated by the Metrology Center and its also makes the vessel became an illegal. The Metrology superintendence of Padang Trade Office continues to supervise, inspect, and provide appeals to all owners of measurements, weighing, and equipment to implement the law properly. This research is a qualitative research with a descriptive method. The research information was determined by purposive sampling and random sampling techniques which are Padang Trade Office, The Regional Technical Implementation Unit of The Metrology Center, some of Gas Stations, and the society. The result of this research is the performance of Mterology superintendence is not optimal due to several factors found in the field such as lack of expert personnel, facilities and infrastructure and budget. The efforts made are submissions to increase the number of experts, use facilities and infrastructure properly, submit additional budgets to government, and conduct socialization and appeals to the owners of the measuring instruments, weighing instruments and the equipment.

Keywords: Pperformance, Trade Office, Controlling

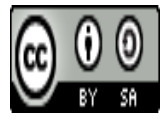

Received: July 26, $2019 \quad$ Revised: July 30, 2019 Available Online: July 31, 2019 


\section{Pendahuluan}

Negara Indonesia memang sudah terkenal dengan berlimpahnya Sumber Daya Alam yang tersebar diberbagai daerah. Kebijakan pemerintah dalam memanfaatkan kekayaan alam yang dimiliki Indonesia digunakan sebagai penunjang taraf kehidupan masyarakat Indonesia dengan harapan akan terciptanya keadilan, kesejahteraan, dan dapat terwujudnya kehidupan masyarakat yang adil dan makmur. Minyak dan Gas Bumi adalah salah satu bentuk dari kekayaan alam yang dimiliki Indonesia. Hal tersebut dibuktikan melalui pernyatan yang disampaikan Dirjen Migas Kementrian ESDM, IGN Wiratmaja Puja dalam detik finance yang menyatakan bahwasannya Cadangan minyak Indonesia bukan hanya 3,7 miliar barel. Masih terdapat 21,5 miliar barel yang proven namun tidak ekonomis untuk diekstraksi. Kekayaan Indonesia akan Minyak dan Gas Bumi menjadi komoditas vital yang menguasai kehidupan orang banyak serta dalam aspek penunjang kehidupan masyarakat, Minyak dan Gas Bumi menjadi salah satu faktor penting dalam perkembangan perekonomian Indonesia.

Menurut (Mubarak, 2014) seiring perkembangan kbutuhan dan tuntutan masyarakat serta usaha untuk merealisasikan tujuan Negara, pemerintah mengalami perkembangan fungsi dan pemerintah. Pemerintahan mengemban tiga fungsihakiki yaitu pelyanan, pemberdayaan, dan pembangunan. Dari tiga fungsi ini dapat dikelompokkan menjadi dua fungsi yaitu fungsi primer dan fungsi sekunder. Fungsi Primer merupakan fungsi yang terus menerus berjalan dan berhubungan positif dengan kondisi pihak yang diperintah. Fungsi sekunder adalah fungsi yang berhubungan negatif dengan kondisi ekonomi, politik, sosial masyarakat.

Pengaturan atau regulasi akan pemanfaatan minyak dibutuhkan guna menjaga kekayaan alam indonesia agar terlepas dari tindak penyalahgunaan serta sebagai upaya dalam menjaga ketersediaan minyak agar tidak cepat habis mengingat besarnya konsumsi minyak di Indoensia yang terus meningkat hingga 2,2 juta bph sehingga impor minyak merupakan suatu tindakan yang tidak dapat dihindarkan. Pemerintah bersama Pertamina bekerjasama dalam melakukan pengendalian, pengawasan, serta pengelolaan dan pendistribusian minyak dan gas bumi kepada masyarakat namun tidak terlepas dari pengawasan Badan Pengatur Penyediaan dan Pendistribusian Bahan Bakar Minyak dan Gas Bumi.

Dikutip dari berita Dunia Energi mengenai kasus pencurian minyak di Indonesia sudah terjadi sejak 2010 hingga sekarang Indonesia selalu menjadi perhatian oleh International Energy Agency akibat besarnya kerugian yang dialami oleh Negara karena pencurian minyak Pertamina yang dilakukan oleh oknum-oknum tidak bertanggung jawab secara masif dan bersifat transnasional. Dikutip dalam Kompas.com bahwasannya pencurian BBM sering dilakukan oleh sopir dan kernet truk tangki dengan menggunakan modus merusak segel kran tangki dan mengurangi takaran BBM dalam mobil tangki tersebut. Kerugian yang dialami Pertamina akibat berbagai kasus pencurian minyak ini hampir mencapai 500 milyar.

Adanya pencurian BBM memberikan dampak negatif bagi pemilik atau pengelola SPBU Pertamina dan secara tidak langusung dalam kasus ini masyarakat juga menjadi korban atas kejadian tersebut. Akibat kerugian yang dialami karena pencurian BBM SPBU menjadikan pemilik atau pengelola SPBU mengambil tindakan untuk meminimalisir kerugian tersebut.

Keluhan akibat kerugian yang ditimbulkan dari perkara pencurian minyak yang berasal dari hulu memberikan dampak besar bagi pemilik SPBU. Dari hasil wawancara penulis dengan Bapak Erik selaku bagian pengawas di Dinas Perdagangan mengemukakan bahwa ada SPBU nakal yang melanggar UU Nomor 8 Tahun 1999 tentang Perlindungan Konsumen Pasal 4 dan Pasal 7:

"Saat sekarang ini ada beberapa SPBU nakal yang memanfaatkan perkembangan zaman dengan memakai remote sebagai pengendali dalam pengisian bensin kepada konsumen yangmana pemilik SPBU mengubah ukuran satu liter itu menjadi 0,78 liter atau kurang dari 1 liter" 
Eksistensi bejana merupakan sebuah solusi akibat kasus pencurian minyak yang terjadi. Bejana merupakan salah satu alat ukur minyak yang berperan sebagai wadah penampung minyak dan sebagai hukum dalam menetukan liter minyak. Bejana merupakan salah satu UTTP yang memiliki tingkat tinggi akurat dibandingkan dengan satuan ukur meteran yang biasa digunakan oleh pihak SPBU. Sesuai dengan Peraturan Menteri Perdagangan Republik Indonesia Nomor 26/ M-DAG/ PER/ 5/ 2017 tentang Pengawasan Metrologi Legal menyatakan bahwa Metrologi Legal adalah metrologi yang mengelola satuan-satuan ukuran, metodametoda pengukuran, dan alat-alat ukur yang menyangkut persyaratan tekik dan peraturan berdasarkan Undang-Undang yang bertujuan melindungi kepentingan umum dalam hal kebenaran pengukuran.

Selanjutnya dijelaskan bahwasannya Pengawasan Metrologi Legal dilaksanakan terhadap UTTP, BDKT, dan Satuan Ukuran untuk memastikan pengunaan UTTP sesuai dengan ketentuan, kebenaranhasil pengukuran, penakaran dan penimbangan; dan adanya tanda tera atau surat keterangan tertulis pengganti tanda sah atau tanda batal. Peredaran bejana sudah mulai tampak sejak tahun 2016 untuk wilayah Sumatera (Aceh, Medan, Padang Sidempuan, Riau, Padang, Jambi, Palembang dan Lampung). Untuk daerah Padang terdapat 25 SPBU yang diawasi oleh Dinas Perdagangan dan beberapa diantaranya telah memasang Bejana Ukur disertai dengan Izin Tanda Pabrik. Saat ini pelaku usaha yang memproduksi Bejana di Kota Padang kurang lebih ada 5 orang. Namun hanya terdapat 1 pelaku usaha yang memiliki izin legal dari Unit Pelaksana Teknis (UPT) Metrologi Legal, Dinas Perindustrian dan Pedagangan Kota Bandung (pusat), dan telah memenuhi standar yang ditentukan dari pusat. Persebaran Bejana di Kota Padang belum semuanya memiliki izin legalitas yang berupa Izin Tanda Pabrik sehingga mengakibatkan bejana yang telah dipasang di SPBU tidak diakui. Hal tersebut terjadi dikarenakan kelalaian pemilik SPBU dalam mematuhi Peraturan Menteri Nomor 23 Tahun 2018 tentang Izin Pembuatan Alat-Alat Ukur, Takar, Timbang, dan Perlengkapannya Produksi Dalam Negeri bahwa setiap UTTP yang telah dipasang di SPBU wajib untuk mencatumkan nomor Izin Tanda Pabrik. Kelalaian yang terjadi dikarenakan pihak pemilik SPBU belum melakukan pemohonan kepada pelaku usaha bejana untuk memberikan label Izin Tanda Pabrik (ITP) sehingga bejana yang yang belum memiliki ITP tidak bisa dilakukan Tera atau Tera Ulang oleh Balai Metrologi Daerah (Kota Padang).

Sebagaimana yang telah diatur dalam UU No.2 tahun 1981, pasal 12 huruf B, Metrologi Legal bahwa UTTP wajib melakukan tera dan tera ulang serta memenuhi syarat-syarat yang harus dipenuhi. Oleh sebab itu, sebagian dari bejana yang telah beredar di SPBU Kota Padang yang saat ini belum memiliki izin tanda pabrik berstatus legal namun tidak diakui. Sesuai dengan Peraturan Walikota Padang Nomor 87 Tahun 2016 tentang Kedudukan, Susunan Organisasi, Tugas, Fungsi, dan Tata Kerja Dinas Perdagangan pasal 19 yang mengatakan bahwa Dinas Perdagangan seksi Pengawasan Kemetrologian bertugas untuk melaksanakan kebijakan pengawasan alat ukur takar timbang dan perlengkapannya, barang dalam keadaan terbungkus, dan SI.

Akibat belum dilakukannya tera atau tera ulang oleh Balai Metrologi terhadap beberapa bejana yang belum mengajukan tera atau tera ulang, mengakibatkan kasus kehilangan minyak masih terjadi di SPBU. Sehingga konsumen atau masyarakat menjadi korban permainan SPBU demi meminimalisir kerugian yang diakibatkan oleh adanya pencurian minyak ataupun penyusutan.Tindakan tersebut melanggar Undang-Undang Nomor 8 Tahun 1999 tentang Perlindungan Konsumen Pasal 4 yang mengatur Hak konsumen untuk diperlakukan atau dilayani secara benar dan jujur serta tidak diskriminatif serta hak atas kenyamanan, keamanan, dan keselamatan dalam mengkonsumsi barang dan/atau jasa. 


\section{Metode Penelitian}

Penelitian yang peneliti gunakan yaitu jenis penelitian kualitatif dengan menggunakan pendekatan deskriptif. Penelitian deskriptif merupakan suatu upaya untuk mendeskripsikan atau menggambarkan tentang keadaan atau peristiwa sebagaimana adanya. Penelitian kualitatif adalah penelitian yang menghasilkan data deskriptif berupa kata-kata tertulis atau lisan dari orang-orang atau perilaku yang diamati (Moleong, 2005). Dengan metode ini, peneliti berupaya menggambarkan kinerja Dinas Perdagangan Kota Padang dalam melakukan pengawasan terhadap penggunaan Bejana di SPBU. Penelitian ini dilakukan di Dinas Perdagangan Kota Padang, UPTD Balai Metrologi, SPBU, dan masyarakat sebagai konsumen BBM di Kota Padang. Informan penelitian ditentukan dengan pertimbangan yang dipandang dapat memberikan data secara maksimal, bersedia meluangkan waktu, dan memberikan keterangan yang dibutuhkan. Pemilihan dan penetapan informan dilakukan dengan karakteristik penelitian kualitatif yaitu teknik purposive sampling dan random sampling. Purposive Sampling adalah informan dipilih dengan sengaja berdasarkan tujuan penelitian oleh peneliti. Penggunaan teknik purposive sampling dalam penelitian ini dimaksudkan untuk mengambil sejumlah orang yang dipilih oleh peneliti berdasarkan kriteria yang dimiliki oleh orang tersebut. Informan dalam penelitian sebanyak 15 orang yang terdiri dari Kepala Dinas Perdagangan Kota Padang, Kepala Bidang Pengawasan dan Stabilisasi Harga, Pelaksana Tugas Pengawasan Kemetrologian, Staff Bidang Pengawasan Kemetrologian, Personil Tata Usaha Kemetrologian, Pemilik SPBU dan masyarakat di Jalan Sawahan, Jalan Jati, dan Jalan Khatib Sulaiman.

Jenis data yang digunakan yaitu data primer dan data sekunder. Data Primer data yang diambil secara langsung dari sumber informasi atau informan penelitian melalui wawancara dan observasi yang berkaitan dengan kinerja Dinas Perdagangan Kota Padang dalam melakukan pengawasan terhadap penggunaan Bejana di SPBU. Data sekunder adalah data yang menunjang dan relevan dengan kajian penelitian yang diperoleh melalui dokumen (laporan jumlah SPBU yang menggunakan Bejana, Sturktu Organisasi, Visi dan Misi, dan lainnya) dan dokumentasi. Uji keabsahan data dalam penelitian dipakai adalah teknik triangulasi sumber. Teknik triangulasi digunakan untuk membandingkan data hasil pengamatan dengan hasil wawancara dengan isi suatu dokumen terkait, dan membandingkan teori dengan pelaksanaannya dalam prakteknya. Kemudian untuk analisis data dilapangan, peneliti menggunakan pendapat Miles dan Huberman yaitu pengumpulan data, reduksi data, penyajian data, dan penarikan kesimpulan atau verifikasi.

\section{Hasil Penelitian dan Pembahasan}

\section{Kinerja Dinas Perdagangan Kota Padang Dalam Melakukan Pengawasan Terhadap Penggunaan Bejana SPBU di Kota Padang}

Kinerja menurut (Fahmi, 2016) menjelaskan bahwa Kinerja merupakan suatu hasil kerja yang dapat dicapai oleh seseorang atau kelompok orang dalam suatu organisasi baik secara kualitatif maupun secara kuantitatif, sesuai degan kewenangan, tugas, dan tanggung jawab untuk mencapai tujuan organisai. Menurut (Wibowo, 2012), baiknya kinerja suatu organisasi tidak hanya dalam bentuk sumber daya manusia saja melainkan juga dalam bentuk modal, bahan-bahan, peralatan, dan teknologi serta metode dan mekanisme kerja. Keseluruhan sumber daya yang dimiliki oleh suatu organisasi harus dapat dikelola secara sinergis. (Wibowo, 2012) menjelaskan bahwa terdapat tiga elemen yang mendukung kinerja suatu organisasi, diantaranya: 


\section{Sumber Daya Manusia}

Banyaknya alat Ukur Takar Timbang dan Perlengkapnnya (UTTP) yang digunakan oleh masyarakat Kota Padang yang berjumlah 386.000 buah dirgolongkan kedalam berbagai bentuk dan jenis. Jumlah tersebut tidak sebanding dengan jumlah aparatur pengawasan kemetrologian yang ada di Dinas Perdagangan Kota Padang. Saat ini yang berada di bidang pengawasan kemetrologian Dinas Perdagangan Kota Padang terdiri atas Kepala Bidang Pengawasan Kemtrologian, Pelaksana Tugas Lapangan dan 2 orang Tenaga Ahli dan dibantu oleh beberapa orang penera dari UPTD Balai Metrologi. Dalam bidang tersebut, terdapat kekosongan jabatan pada bagian Kepala Seksi Pengawasan Kemetrologian sehingga perintah langsung diturunkan dari Kepala Bagian ke Pelaksana Tugas (PLT). Kekosongan jabatan tersebut sudah terjadi dalam 1 tahun dikarenakan terjadinya mutasi pada pegawasi tersebut. Keberadaan tenaga ahli yang ada dibidang tersebut sebagai aparatur yang melakukan pemeriksaan terhadap alat UTTP juga mengambil peran sebagai pengamat keadaan dan kelayakan dari alat UTTP sehingga terjadinya double job dalam satu peran. Ketiadaan Pengawasa Pegawai Negeri Sipil di bidang kemetrologian juga merupakan bagian dari permasalahan yang ada pada Dinas Perdaganga Kota Padang karena untuk turun kelapangan menjalankan tugas dan melakukan pemeriksaan dibutuhkan minimal satu orang Metrologi, satu orang Pengawas, dan satu orang Penera. Keterbatasan sumber daya manusia tidak hanya mencakup pada tenaga ahli melainkan juga kurangnya orang yang melakukan pendataan terhadap perkembangan atau pembaharuan alatalat UTTP yang ada. Bentuk bantuan personil oleh dinas provinsi kepada bidang metrologi pengawasan Kota Padang juga terbatas pada keahlian dan kemampuan yang dimiliki sebab tidak memiliki pendidikan dasar mengenai alat dan pengetahuan bidang kemetrologian.

\section{Metode Kerja}

Dalam kaitannya dengan kinerja, metode kerja dan proses kerja merupakan hal yang sangat berpengaruh terhadap hasil kerja sebuah organisasi. Oleh sebab itu, pemimpin harus mampu menilai dan melihat apakah metode yang digunakan sudah tepat atau masih dapat disempurnakan guna meningkatkan kinerja organisasi. Dalam hasil penelitian yang telah penulis analisa dapat ditemukan bahwa ada beberapa langkah kerja yang dilakukan oleh Dinas Perdaganga Kota Padang bidang Pengawasan Kemetrologian yeng terdiri atas Perencanaan yang terkait dengan jumlah personil yang akan turun ke lapangan seperti jumlah penera, pengamat, dan pengawas. Sarana dan Prasarana yang mencakup alat uji, transportasi, dan anggaran. Strategi atau taktik yang digunakan saat akan melakukan pengamatan. Kelengkapan Administrasi seperti data-data terait, laporan masyarakat, surat perintah tugas, dan surat pemberitauan. Perencanaan dilanjutkan dengan kegiatan pelaksanaan pengawasan yang dilakukan berdasarkan hasil analisis situasi, data-data dan laporan dari Pengamat Pegawai Negeri Sipil dan masyarakat. Ketika kegiatan pengawasan telah dilakukan makan pelaporan atas hasil dari kegiatan pengawasan tersebut dijadikan sebagai bahan evaluasi atas kinerja pegawai pengawas kemetrologian di lapangan.

\section{Sarana dan Prasarana}

Berdasarkan hasil penelitian dan analisa yang penulis lakukan di Dinas Perdagangan Kota Padang ditemukan bahwasannya terdapat beberapa hal yang terkait dengan sarana dan prasarana yang ada sehingga menghambat kerja para pegawai Dinas Perdagngan Kota Padang khususnya Bidang Pengawasna Kemetrologian. Adapun kendala-kendala tersebut terdiri dari terbatasnya alat uji labor yang dimiliki oleh bidang pengawas kemetrologian. Terbatasnya kepemilikian atau kesediaan bejana ukur standar. Serta terbatasnya perlatan uji yang mengikuti perkembangan teknologi saat ini diakrenakan masih banyak alat-alat uji yang masih bersifat manual dan belum memeliki alat uji elektronik. Selain dari adanya kendala pada alat-alat labor, minimnya ketersediaan alat transportasi juga dialami oleh bidang pengawasan kemetrologian. 
Transportasi yang dimiliki oleh bidang pengawas kemetrologian adalah satu buah bus yang disediakan Dinas diperuntukkan kepada bidang pengawasan kemetrologian, namun lebih sering digunakan oleh kepala bidang pengawasan \& stabilisai harga dibandingkan oleh para tenaga ahli yang akan turun kelapangan. Keterbatasan tidak hanya pada alat uji dan transportasi. Anggaran merupakan satu diantaranya. Terbatasnya dana yang diperuntukkan kepada bidang pengawasan kemetrologian disebabkan karena bidang ini tidak memberikan Pendapatan Anggaran Daerah yang besar, sehingga ketika bidang Pengawasan Kemetrologian memberikan proposal pengajuan anggaran kepada Kepala Dinas Perdagangan Kota Padang selalu mendapatkan penundaan. Maka mulai dari tahun 2016 awal berdirinya Dinas Perdaganga Kota Padang yang merupakan gabungan dari Dinas Pasar, keterbatasan alat uji, transportasi dan anggaran sudah menjadi hal yang biasa di Bidang Pengawas Kemetrologian.

\section{Kesimpulan}

Berdasarkan hasil analisis yang dilakukan terhadap data penelitian guna mengungkap dan menjawab pertanyaan-pertanyaan penelitian yang berhubungan dengan Kinerja Dinas Perdgangan Dalam Melakukan Pengawasan Tehadap Penggunaan Bejana di SPBU, maka dapat disimpulkan bahwa:

1. Kinerja Dinas Perdagangan Kota Padang dalam Melakukan Pengawasan Terhadap Penggunaan Bejana di SPBU dapat dikatakan masih kurang baik. Tidak adanya kejelasan tugas antara pengawas dengan Pengamat Pegawai Negeri Sipil. Waktu yang digunakan untuk melakukan pengawasan tidak memenuhi target. Sasaran dari dilakukannya pengawasan ini ditujukan kepada pengguna Bejana di SPBU namun masih ditemukan Bejana-Bejana yang tidak melengkapi syarat teknis bejana ukur. Kegiatan pengawasan dilakukan secara berkala berdasarkan ketentuan yang telah ditetapkan oleh Dinas Perdagangan. Bentuk pengawasan dilakukan secara langsung yakni dengan mendatangi SPBU dan menganalisa kelengkapan dan keadaan bejana ukur di SPBU. Adapun bentuk pengawasan secara tidak langsung adalah laporan-laporan yang berasal dari pengamat pegawai negeri sipil dan masyarakat.

2. Kendala-kendala yang dihadapi dalam Melakukan Pengawasan Terhadap Penggunaan Bejana SPBU meliputi kendala internal dan eksternal. Kendala internal meliputi keterbatasan jumlah personil Bidang Pengawas Kemetrologian, kurangnya staf Tenaga Ahli, Tidak adanya PPNS, sarana dan prasarana yang kurang serta anggaran yang tidak mendukung, dan tidak adanya insentif sebagai bentuk motivasi kepada pegawai, sedangkan kendala eksternal yaitu lalainya para pemilik atau pengguna bejana ukur dalam mematuhi peraturan yang ada.

3. Upaya yang dilakukan oleh bidang pengawas kemetrologian dalam mengatasi kendalakendala, yaitu: 1) dalam pelaksanaan pengawasan semua staff tenaga ahli melakukan kerjasama dengan UPTD Balai Metrologi dan mengajukan penambahan personil ke Dinas Perdagangan dan Perindustrian Provinsi, 2) mengajukan kepada Kepala Dinas Perdagangan agar menambahkan staff tenaga ahli dan mengajukan personil yang diberikan pelatihan oleh Direktorat Metrologi Bandung, 3) menggunakan sarana dan prasarana yang ada dengan sebaik-baiknya dan mengajukan penambahanalat uji dan alat labor serta penambahan anggaran yang telah diajukan ke Kepala Dinas Perdagangan Kota Padang, dan 4) melakukan sosialisasi kepada pemilik dan pengguna UTTP SPBU di seluruh Kota Padang. 


\section{Daftar Pustaka}

Fahmi, I. (2016). Perilaku Organisasi Teori, Aplikasi dan Kasus. Bandung: Alfabeta.

Keputusan Jendral Perdagangan Dalam Negeri Nomor 23/PDN/KEP/3/2010

Moleong, L. J. (2005). Metode Penelitian Kualitatif. Bandung: Remaja Rosdakarya.

Mubarak, A. (2014). Peran ORMAS Dalam Menjalankan Fungsi Pemerintah Bidang

Pemberdayaan. repository.ut.ac.id.

Peraturan Menteri Nomor 23 Tahun 2018 tentang Izin Pembuatan Alat-Alat Ukur, Takar, Timbang, dan Perlengkapannya Produksi Dalam Negeri

Peraturan Menteri Perdagangan Republik Indonesia Nomor 26/ M-DAG/PER/ 5/2017 tentang Pengawasan Metrologi Legal

Peraturan Walikota Padang Nomor 61 Tahun 2012 tentang Penjajaran Tugas Pokok dan Fungsi Dinas Perindustrian, Perdagangan, Pertambangan, dan Energi

UU No.2 Tahun 1981, pasal 12 huruf B, Metrologi Legal

UU No.8 Tahun 1999, pasal 4, Perlindungan Konsumen

Wibowo. (2012). Manajemen Kinerja cetakan keenam. Jakarta: Raja Grafindo Persada. 